\title{
Regulatory Reform: An Idea to Arrange Regulations in Indonesia
}

\author{
Wicipto Setiadi ${ }^{1, *}$ Beniharmoni Harefa ${ }^{1}$ \\ ${ }^{l}$ Fakultas Hukum Universitas Pembangunan Nasional Veteran Jakarta \\ *Corresponding author. Email wiciptosetiadi@upnvj.ac.id
}

\begin{abstract}
The current regulatory condition in Indonesia, both from the quantity and quality perspectives, is relatively miserable. A non-proportional number of regulations may lead to bad regulations which tend to be sectoral, overlapping, multi-interpretations, conflicting, and unharmonious. Such a regulatory condition may cause legal uncertainty among the society, the people, and the nation. Solving such a condition requires regulatory reform. The idea of regulatory reform is conducted through three ways, namely: substantive regulatory reform, procedural regulatory reform, and institutional reform of regulators. Regulatory reform will be a success with the full support of the top state leaders and the stakeholders. This paper was arranged by employing analyticaljuridical methods and utilizing literature approach and legislation approach as well as other materials related to the subject matter such as journals, papers, and materials accessed from the internet.
\end{abstract}

Keywords: regulation quality, regulation quantity, regulatory reform.

\section{INTRODUCTION}

The current condition of Indonesian regulations, both from the quantity and quality perspectives, is relatively miserable [1]. Until now, there are no certain data of how many regulations are there in Indonesia since different numbers of regulations are presented by many data providers. Besides, the data are also distributed in various institutions. Therefore, from the perspective of quantity, there is non-proportionality of the number of regulations, which leads to hyper-regulation or over-regulated [2].

Hyper regulations are actually not a problem provided that they are not conflicting, overlapping, unharmonious, or multi-interpretative. However, hyper regulations are quite potentially problematic in case of conflict, overlap, disharmony, and multiinterpretations.

According to the observation of the current condition, the hyper regulations in Indonesia cause relatively serious problems in the life of the people and of the nation. Various problems arise as the result of conflicting, overlapping, unharmonious [3] and multi-interpretative hyper regulations.
The substantial number of regulations in Indonesia is caused by the legal tradition applied by Indonesia, namely Civil Law/Continental Europe. The legal tradition is of Dutch legacy, with its about 3.5-century colonization of Indonesia. Civil Law/Continental Europe basically prioritizes written law in the form of laws and regulations.

The Civil Law/Continental Europe legal tradition is usually faced with the Common Law/Anglo Saxon legal tradition, which is based more on non-written law, which is judge/court decision. No clear line can actually be drawn between these two traditions since they actually complete each other. The countries with Civil Law/Continental Europe legal tradition have applied the Common Law/Anglo Saxon legal tradition, and vice versa, the countries with Common Law/Anglo Saxon legal tradition have also applied Civil Law/Continental Europe legal tradition.

Based on the description above, the following problem is taken to limit the paper's discussion: what effort may be conducted to solve hyper regulations, over regulated in Indonesia? 


\section{RESEARCH METHOD}

The research employed analytical-juridical methods and utilized literature approach and discuss regulation. Books, paper, and materials accessed from the internet related to regulations in Indonesia.

\section{FINDINGS AND DISCUSSION}

Based on the database of peraturan.go.id, there are 8,552 regulations at the central level, 15,117 ministerial regulations, 4,468 regulations of the non-ministerial governmental institution, and 15,967 local regulations. However, the total number of regulations in Indonesia is currently 44,104, as stated by the database of peraturan.go.id.

However, many regulations have not been registered with the database of peraturan.go.id. To put it simply, not all regulations are registered in the database of peraturan.go.id, particularly ministerial regulations and local regulations, both at provincial and regency/municipal levels [4].

Besides, the database of peraturan.go.id is not the only provider of regulatory data, that there are other databases which provide regulatory data and the number of regulations they present is different from each other [5]. The detail of regulations is presented in the matrix below.

Laws and Regulations at Central Level

\begin{tabular}{|l|r|}
\hline \multicolumn{1}{|c|}{ Type of laws and regulations } & \multicolumn{1}{c|}{ Total } \\
\hline Laws & 1690 \\
\hline Government Regulation in Lieu of Law & 182 \\
\hline Government Regulation & 4588 \\
\hline Presidential Regulation & 2092 \\
\hline Regulation of BPK & 27 \\
\hline Regulation of BI & 156 \\
\hline Regulation of OJK & 371 \\
\hline Total & 8552 \\
\hline
\end{tabular}

Registered with State Gazette [6]

Ministerial Regulations [7]

\begin{tabular}{|c|c|}
\hline Year & Total \\
\hline $1946-2020$ & 15,117 \\
\hline
\end{tabular}

Regulations of Non-Ministerial

Governmental Institution (LPNK) [8]

\begin{tabular}{|c|c|}
\hline Year & Total \\
\hline $1977-2020$ & 4,468 \\
\hline
\end{tabular}

Local Regulations [9]

\begin{tabular}{|c|c|}
\hline Year & Total \\
\hline $1971-2019$ & 15,967 \\
\hline
\end{tabular}

legislation approach and other materials related to the subject matter such as journals, papers, and materials accessed from the internet. Journal that

\subsection{Substantive Regulatory Reform}

The objective of regulatory reform is to create efficient, effective, simple and orderly regulations. This objective must be implemented synergistically and simultaneously, both to positive law (ius constitutum) and written law that will be arranged (ius constituendum).

The current number of regulations in Indonesia may be deemed non-proportional, particularly regulations below the Law. The issue of non-proportionality of the number of regulations will be solved by applying regulation simplification [10] by simplifying, eliminating, or reducing the existing number of regulations.

Regulatory simplification is an effort to improve the condition of written laws in Indonesia which are empirically viewed and perceived to tend to be overlapping and disharmonious. Such a condition must be improved so that their negative excess will not widen and result in legal uncertainty in their enforcement. This effort is conducted by reviewing the existing and prevailing regulations (positive law), and simplifying them by revoking unnecessary regulations, revising and improving necessary but problematic regulations, and keeping good quality and necessary regulations.

This simplification measure is very important since it may eliminate non-proportional regulations to produce a proportional number of regulations. Regulatory simplification will also ensure the effectiveness of regulations and adjust them to the legal framework and procedure of regulation-making, prevent overlap, simplify the procedure and lessen the cost.

The simplification method is conducted to measure the relevance of regulation to underlying criteria. The criteria are related to the legality aspect, necessity aspect, and procedure friendliness aspect. The legality aspect is intended to review whether no multi-interpretations are found or potential conflict, duplication, inconsistency, or non-operability is found in a regulation.

The necessity aspect is intended to review whether a regulation has a clear objective and is based on the underlying necessity of the public and state administrators. Meanwhile, the procedure friendliness aspect is intended to review whether a 
regulation may be easily understood and complied with and will not pose an excessive burden to any parties directly affected by it. In other words, the objective of regulation may be achieved without posing an unnecessary burden to groups affected by the regulation.

The first step to simplify regulation is to inventory and evaluate prevailing regulations, from regulations of colonial legacy, to the 1945 regulations and 2019 regulations.

\subsubsection{Simplification of Regulation of Dutch Colonial Legacy \\ The first priority is to simplify regulations} of the Dutch colonial legacy. It is unreasonable that Indonesia, which has acquired its independence for 75 years and been free from colonization, has regulations of the Dutch colonial era applicable [11]. Therefore, it is necessary to study the existence and applicability of regulations of Dutch colonial legacy to ensure which regulations remain applicable until now.

What is clear is that until this writing is arranged, the Criminal Codes which are the translation of Wetboek van Strafrecht (WVS) and the Civil Codes which are the translation of Burgerlijk Wetboek (BW) remain applicable. With the application of regulations of Dutch colonial legacy, this means Indonesia currently does not have any truly national Legal System.

We may even state that the Indonesia's Positive Legal System is at least a mixed law of Customary Laws, Islamic Law, Dutch Colonial Law, and Anglo Saxon (Common Law) legal system. Viewing such a condition, eliminating regulations of Dutch colonial legacy takes priority. After 100 years of Indonesia's independence (2045), regulations of the Dutch colonial era should not prevail anymore.

Eliminating regulations of Dutch colonial legacy may be made in two ways, namely complete revocation and partial revocation [12] of laws and regulations of Dutch colonial legacy. From the perspective of the laws and regulations arrangement technique, the two methods are quite a possibility. Complete revocation for some laws and regulations will certainly cause problems compared to partial revocation.

Partial revocation of laws and regulations is the most often and commonly made. Meanwhile, complete revocation of laws and regulations for some laws and regulations is seldom made. Based on the experience of the state administration so far, revocation of laws and regulations with the two methods has been ever made.

Complete revocation of some (all) laws and regulations of Dutch colonial legacy is under strong reason, either philosophically, juridically, and sociologically. The procedure, arrangement technique, discussion, and legalization are quite different from the procedure set forth in Law No. 12 Year 2011 on the Formation of Laws and Regulations amended by Law No. 15 Year 2019.

With the complete revocation of laws and regulations of Dutch colonial legacy, there will be no laws and regulations of Dutch colonial legacy left. It is then to inventory which and how many laws and regulations of Dutch colonial legacy remain applicable carefully and accurately, leaving none left. It will, however, be serious problems that there is a vacancy of laws and regulations after such a complete revocation.

\subsubsection{Simplification of Regulation from 1945 to 2019 \\ Regulations from 1945 until now may be} classified into 4 groups, namely: regulations of the period from 1945 - 5 July 1959, regulations of the Old Order era (from 1959-1965), regulations of the New Order era (from 1965-1998) and regulations of the Reform Order era (from 1998-2019) along with all of their implementing regulations. After inventorying by a group of regulations along with all of their implementing regulations, the next step is to evaluate and analyze problematic regulations (disharmonious, conflicting, overlapping, sectoral ego, and others).

This research's recommendation is to revoke unnecessary regulations (because of disharmony, conflicting, overlapping, sectoral ego, and others), revise regulations with less good quality (because of disharmony, conflicting, overlapping, sectoral ego and others), or keep regulations with good quality.

The problem which arises here is whether the revocation or revision of problematic regulations will be conducted simultaneously for some regulations or partially? When conducted partially, it will take a relatively long time. Considering that partial regulation simplification will take a long time and be costly, an option to adopt the concept of Omnibus Law may be studied [13]. 
Omnibus Law_is a concept from the Common Law (Anglo Saxon) system, while the legal system in Indonesia tends to follow the Civil Law (Europe Continental Europe) system. However, it is currently irrelevant to strictly separate the Common Law and Civil Law systems, that they may complete each other.

Until now, Indonesia has been through some government regimes, from the Old Order to the Reform Order. Changes in President and government cabinet also result in many regulations as desired by each government regime in power. This causes overlapping regulations and a conflict of policies between one ministry/department and the other.

\subsection{Procedural Regulatory Reform}

Based on Law No. 12 Year 2011 on the Formation of Laws and Regulations as amended by Law No. 15 Year 2019, law and regulation-making procedure is not simple, and may even be deemed complicated, particularly related to regulatory amendment or reform.

The constraints in regulatory reform are related to the harmonization procedure. Harmonization applies the principle that during drafting regulations, there should be no conflict, overlap, and disharmony between one regulation and the other, either with higher, equal, or lower regulations.

Solving such regulatory problems requires a legal breakthrough and one of the ways is through the concept of Omnibus Law [14]. Some countries have applied Omnibus Law, including the United States (The Omnibus Act of June 1868, The Omnibus Act of February 22, 1889), Canada (Criminal Law Amendment Act, 1968-69), Philippines (Tobacco Regulation Act of 2003), and 39 countries which adopt Omnibus Law in terms of personal data protection, including Argentina, Australia, Austria, Belgium, Canada, Chile, Czech Republic, Denmark, Estonia, Finland, France, Germany, Greece, Hungary, Iceland, Ireland, Israel, Italy, Japan, Latvia, Liechtenstein, Lithuania, Luxembourg, Malta, the Netherlands, New Zealand, Norway, Poland, Portugal, Romania, Russia, Slovak Republic, Slovenia, Spain, Sweden, Switzerland, Taiwan, Thailand, and United Kingdom [15].

Law-making using the omnibus law approach has actually been conducted far before the omnibus law approach is used in making Bill of Job Creation, in the drafting of Law No. 13 Year 2003 on Labor Affairs. The approach used to draft the Law of Labor Affairs is to arrange new provisions as currently needed and the old provisions in old laws and regulations are revoked. To contain the newly formulated provisions, Law No. 13 Year 2003 revokes and declares as null and void 6 ordinances and 9 laws simultaneously [16].

The ordinances revoked by Law No. 13 Year 2003 on Labor Affairs are: [17]

1. Ordinance on Recruitment of the Indonesians for Working Outside Indonesia (Staatsblad Year 1887 Number 8);

2. Ordinance on Limitation of Child Work and Night Work for Women (Staatsblad Year 1925 Number 647);

3. Ordinance on Child and Youth Work on Ship (Staatsblad Year 1926 Number 87);

4. Ordinance on Regulation on Activities to Recruit Potential Workers (Staatsblad Year 1936 Number 208);

5. Ordinance on Repatriation of Workers Accepted or Recruited from Out of Indonesia (Staatsblad Year 1939 Number 545);

6. Ordinance on Child Work Limitation (Staatsblad Year 1949 Number 8).

Meanwhile, the laws revoked by Law No. 13 Year 2003 on Labor Affairs are: [18]

1. Law No. 1 Year 1951 on Statement of the Application of Law on Employment Year 1948 Number 12 of the Republic of Indonesia for All the Indonesians (State Gazette Year 1951 Number 2);

2. Law No. 21 Year 1954 on Labor Agreement between Labor Union and Employer (State Gazette Year 1954 Number 69, Supplement to State Gazette Number 598a);

3. Law No. 3 Year 1958 on Deployment of Foreign Worker (State Gazette Year 1958 Number 8);

4. Law No. 8 Year 1961 on Graduate Mandatory Apprenticeship (State Gazette Year 1961 Number 207, Supplement to State Gazette Number 2270);

5. Law No. 7 Pnps Year 1963 on Prevention of Strike and/or Lock-Out at Company, Service Company and Vital Body (State Gazette Year 1963 Number 67);

6. Law No. 14 Year 1969 on the Man Provisions of Labor Affairs (State Gazette Year 1969 Number 55, Supplement to State Gazette Number 2912):

7. Law No. 25 Year 1997 on Labor Affairs (State Gazette Year 1997 Number 73, Supplement to State Gazette Number 3702); 
8. Law No. 11 Year 1998 on the Amendment to the Application of Law No. 25 Year 1997 on Labor Affairs (State Gazette Year 1998 Number 184, Supplement to State Gazette Number 3791);

9. Law No. 28 Year 2000 on the Stipulation of Governmental Regulation in Lieu of Law No. 3 Year 2000 on the Amendment to Law No. 11 Year 1998 on the Amendment to the Application of Law No. 25 Year 1997 on Labor Affairs to be Law (State Gazette Year 2000 Number 240, Supplement to State Gazette Number 4042)

There are advantages and disadvantages of the application of the concept of Omnibus Law in reforming regulations in Indonesia. The advantages of the application of Omnibus Law in Indonesia include: [19]

a. It solves conflicts of laws and regulations quickly, effectively, and efficiently.

b. It uniforms government policies, both at central and local levels, in support of investment climate;

c. More integrated, efficient and effective licensing administration;

d. It is able to cut the long chain of bureaucracy;

e. It improves the coordination between related institutions that it is set forth in an integrated policy of Omnibus Law;

f. There is guaranteed legal certainty and legal protection for policy-makers.

The disadvantages of the application of the concept of Omnibus Law in Indonesia include: [20]

1) There is possible rejection in the final stage or at judicial review of the issued policy of Omnibus Law;

2) Legislatives will feel "castrated" since laws and regulations are made without legislative's involvement;

3) It will influence the stability of the national legal system resulting from the changing orientation of government policies as desired by the regime in power.

Revocation and declaration as null and void of many regulations will cause an adverse impact on related parties and will usually be rejected or resisted, for example, the pro and contra on the current Bill of Job Creation which was the Government's initiative and under the approval of the Plenary Session of the House of Representatives on 5 October 2020. The Bill of Job Creation was arranged by applying the omnibus law approach by arranging new norms and revoking and declaring null and void as well as revising norms set forth in 79 laws.
In case the revocation and declaration as null and void of the regulations are deemed detrimental, it will cause rejection or resistance of those considering themselves harmed. The President shall have 30 days after receipt of the Bill to sign it. If the bill has been approved by the House of Representatives, whether the President signs it or not will not affect the applicability of the Bill of Job Creation.

Based on the pro and contra arising from the Bill of Job Creation, the measures which need to be made in regulatory reform through the omnibus law approach is to perform an in-depth and comprehensive study on it. The study may be in the form of Academic Script, including regarding cost and benefit analysis, followed with inventorying of how many regulations are existing and which regulations are affected by it and what legal acts to be made with the affected regulations, whether they will be revoked, superseded, revised or any other legal acts.

Regardless of the pro and contra regarding the omnibus law application, omnibus law is an approach/method which needs to be taken into consideration in reforming regulations in Indonesia. As the consequence of the application of the omnibus law method, it is necessary to revise Law No. 12 Year 2011 on the Arrangement of Laws and Regulations as amended by Law No. 15 Year 2019.

It is necessary to amend Law No. 12 Year 2011, particularly related to laws and regulations making procedure and technique. By brief observation, the drafting of Bill of Job Creation is not entirely based on or in accordance with laws and regulations drafting technique, while Article 64 Law No. 12 Year 2011 stipulates: (1) A Bill is arranged pursuant to the laws and regulations arrangement technique. (2) The provisions of laws and regulations arrangement technique as referred to in paragraph (1) is contained in Appendix II which is an integral part of this Law.

\subsection{Regulation Making Institution Reform}

Discussion on legislation quality and quantity cannot be separated from the activities of regulation-making institutions or stakeholders themselves, particularly those of political institutions. Inevitably, we should also learn and discuss actors that hold the role. A political study in the legislation process helps us understand to what extent rationality is made the base of decisionmaking among various political choices [21]. 
This is in line with HAS Natabaya's idea that assessing the quality of laws and regulations should observe from upstream to downstream. Laws and regulations are political products with two meanings: the first meaning, politics in the sense of policy, which is a regulation which binds the formation of laws and regulations, and the second meaning, politics in the sense of political practice [22].

Therefore, a legal product will be greatly determined or filled with political balance or configuration from which it is born. This idea is based on the fact that each law is a political decision, thus it may be viewed as the crystallization of political ideas which interacts with each other among politicians. Therefore, according to Mahfud, the political configuration will also generate a certain character of the legal product.

Further, Mahfud divides democratic political configuration with authoritarian political configuration. Mahfud states that a democratic political configuration will generate legal products with responsive or autonomous character, while an authoritarian political configuration will generate conservative/orthodox or oppressive legal character [23].

Laws and regulations making cannot be separated from institutions' necessity and role. The existing institutions have not optimally supported laws and regulations making since they are sectoral. Therefore, it is necessary to assign certain institutions for law planning and formation in a centralized manner for an intact and comprehensive system.

For a successful regulatory reform, institutional restructuring in making laws and regulations should be made entirely at branches of executive, legislative and judicative power, even if we are aware that restructuring laws and regulations making institutions are not easy since this is related to institutional authority and state financial burden.

Restructuring regulation-making institutions at the executive power branch takes priority and is directed to a one-stop regulationmaking policy, in which the authority is currently distributed to almost all ministries and nonministerial governmental institutions (LPNK). What is meant by a one-stop regulation-making policy is the policy to integrate the authority to make regulation which is distributed to various institutions into only one institution.
This policy is based on current experience, that with so many regulation-making institutions, there is an attraction of authority between institutions, which also frequently raises sectoral ego. Consequently, many regulations produced are disharmonious, overlapping, and conflicting.

Ideally, the President needs to establish a special ministry to handle all regulation-making processes at executive power branches. The nomenclature of such ministry may be Ministry of Regulation or Ministry of Laws and Regulations. The ministry's human resources may be of with a combination of 2 units of echelon 1 of the Ministry of Law and Human Rights, including that of the National Law Supervisory Body and the Director General of Laws and Regulations, Department of Law and Legislation of the Ministry of the State Secretariat, Department of Cabinet Secretariat, and 1 unit of echelon 1 at the Ministry of Home Affairs. Ministry of Regulation or Ministry of Laws and Regulations must be filled with truly professional, credible and competent personnel, instead of those from political parties.

In the Presidency environment, there is only one institution, which is the State Secretariat, which is an integration of Cabinet Secretariat (nonlegislation function) and the Office of President Staffs without Department of Laws and Regulations. Ministries and other LPNKs may only propose a bill of law to the Ministry of Regulation or Ministry of Laws and Regulations and the Ministry of Regulation or Ministry of Laws and Regulations will proceed to arrange it. The one-stop institution for laws and regulations making must also be supported with good tools, since if otherwise, regulatory reform will not proceed well. Besides competent human resources, the Ministry of Regulation or Ministry of Laws and Regulations must also be supported with advanced IT.

For comparison, some countries have an institution with special tasks and functions to handle regulations. In South Korea, regulatory issues are handled by the Ministry of Government Legislation (MOLEG). MOLEG is an institution under the Prime Minister and is independent [24]. MOLEG is established aiming at controlling the process of legislation in the government environment and perform a complete review in the enactment process so that lower regulations which are contradictory to higher regulations will not be enacted [25]. Besides South Korea, the United States also has The Office of Information and Regulatory Affairs (OIRA) [26]. Japan has the 
Cabinet Legislation Bureau [27] and Australia has the Department of the Prime Minister and Cabinet [28].

Regulations at the local level should remain decentralized, instead of centralized. A special institution is also needed to handle regulations at the local level. This institution shall be at the provincial level with the same functions as that at the central level to effectively plan, propose and coordinate regulations making at the local level. Regulations at the local level, besides regulating problems pursuant to local necessity and characteristics should also refer to the central regulations.

Further, institutional restructuring also needs to be made at the legislative power branch. Drastic changes also need to be made with the legislative power branch, in which Bill proposal which is initially proposed through many institutions is currently made with a one-stop institution, namely through the Legislation Body (Baleg) of House of Representatives. Consequently, this institution must be supported with strong and competent human resources and advanced IT.

This is certainly not easy, since the commission or other auxiliary instrument will not involuntarily release their authority for Bill proposal. The commission or other auxiliary instrument will maintain their authority for Bill proposal as strongly as they are capable of, since the authority to propose Bill at the House of Representatives is a very important and strategic authority.

As the consequence of the policy of onestop authority for Bill proposal at Baleg of the House of Representatives, members of Baleg should focus and concentrate on Law-making and not take the office of any commission or other auxiliary instrument and other committees. Practically, many members of the House of Representatives involved in Bill discussion are often absent on the reason of other tasks at the commission, committee, or other auxiliary instruments. Therefore, the task of Baleg of the House of Representatives gets heavier and more difficult, thus Baleg should be supported with truly professional and competent experts and advanced IT. Members of Baleg of the House of Representatives also need to be equipped with the knowledge of laws and regulations drafting.

In addition, from the technical perspective of Problem Inventory Register (DIM) of the House of Representatives of Bill from the Government should only be one, which is DIM of the House of Representatives instead of DIM of fractions. This is the same with DIM of Government on the House of Representatives' Bill shall only be one, which is DIM of the Government. With only one DIM, the discussion will be easier and more concentrated compared with many DIMs from fractions.

There are currently 9 party representatives, namely PDI-P, Golkar, Gerindra, Nasdem, PKB, Demokrat, PKS, PAN, and PPP, with seats at the House of Representatives, thus DIM of Bill at the House of Representatives is the input from 9 parties. With only one DIM, discussion on Bill at the House of Representatives is expected to be simpler and more quickly settled. The discussion shall be directed more on matters related to the substance or materials, while drafting technical matter shall be submitted to the drafter.

For the judicative power branch, even if it is not the direct legislator, but it serves as the institution which performs the judicial review, it also needs a one-stop institution policy. Why is the one-stop policy in laws and regulations review needed? The laws and regulations review is currently conducted by two institutions, namely the Constitution Court (MK) for Law review and by the Supreme Court (MA) for review of laws and regulations below the Law.

The one-stop idea for judicial review at MK is the effort to confirm that MK is a court of law, and MA is a court of justice, since the judicial review is included in the court of law domain instead of the court of justice domain [29]. Practically, it will be very difficult for the party which applies for judicial review because of the matter of law or because of the matter of justice, since many also apply judicial review for justice.

In the future, review of laws and regulations shall only be conducted by $\mathrm{MK}$, and there is no need for differentiation between Law review by MK and review of laws and regulations below the Law by MA [30]. Transfer of authority to review regulations under the Law from MA to MK is reasonable since MA is an institution which is highly busy with many cases, thus the transfer of authority will relieve MA's works. In addition, MA, with a limited number of human resources, must handle tens of thousands of cases annually [31]. As the consequence of a one-stop policy for the authority to review laws and regulations by $\mathrm{MK}$, it is necessary to amend Article 24A of the 1945 Constitution of the Republic of Indonesia and 
harmonize and synchronize with the Law on Judicial Power, Law on MA, and Law on MK.

In addition, MK should remain consistent to be the "negative legislator" (as reviewer) instead of the "positive legislator" (to amend or draft new norms). As the consequence of "negative legislator", MK may only decide or state whether or not a Law reviewed is contradictory to the constitution without amending or formulating new norms. Such amendment or new norm formulation should not be taken over by MK since principally an amendment to or new formulation of a Law is the "positive legislator's" authority.

\section{CONCLUSION}

Based on the explanation above, regulatory reform is the effort to arrange regulations. Considering that the Indonesian regulations are currently in a miserable condition from the perspectives of quantity and quality, the effort of regulatory reform is then quite urgent. Regulatory reform may at least be made through 3 methods, namely substantive reform, procedural reform, and reform of regulation-making institutions. The success of the effort requires the full support of the state's top leaders.

\section{REFERENCES}

[1] Wicipto Setiadi. (2020). SIMPLIFIKASI REGULASI DENGAN MENGGUNAKAN METODE PENDEKATAN OMNIBUS LAW [REGULATORY SIMPLIFICATION USING OMNIBUS LAW APPROACH METHOD]. Rechts Vinding Journal: National Law Supervisory Media, 9(1), 39. Retrieved from https://rechtsvinding.bphn.go.id/ejournal /index.php/jrv/article/view/408/239.

[2] Wicipto Setiadi. (2018). SIMPLIFIKASI PERATURAN PERUNDANG-UNDANGAN DALAM RANGKA MENDUKUNG KEMUDAHAN BERUSAHA [SIMPLIFICATION OF LAWS AND REGULATIONS IN SUPPORT OF BUSINESS FACILITATION]. Rechts Vinding Journal: National Law Supervisory Media, 7(3), 321-334. Retrievedfromhttps://rechtsvinding.bphn.go.id lejournal/index.php/jrv/article/view/288/203.

[3] Compare: Wicipto Setiadi, Proses Pengharmonisasian Sebagai Upaya Untuk Memperbaiki Kualitas Peraturan Perundangundangan [Harmonization Process as an Effort to Improve the Quality of Laws and
Regulations], Indonesian Legislation Journal, Vol. 4 Number 2, June 2007, Directorate General of Laws and Regulations, Department of Law and Human Rights of the Republic of Indonesia, p. 46.

[4] Wicipto Setiadi, Op. Cit.

[5] Compare Wicipto Setiadi, Op. Cit.

[6] https://peraturan.go.id/peraturan/pusat.html accessed on 10 October 2020 at 21.06.

[7]. https://peraturan.go.id/peraturan/list.html?id= 11e449f371bb47e09607313231373436 accessed on 10 October 2020 at 21.30.

[8]. https://peraturan.go.id/peraturan/list.html?id= 11e45da5a04bb002ae96303235313036 accessed on 10 October 2020 at 21.48 .

[9]. https://peraturan.go.id/peraturan/list.html?id= 11e449f37c133b90991d313231383033 accessed on 10 October 2020 at 22.53 .

[10] In Kamus Besar Bahasa Indonesia (KBBI), simplifikasi (simplification) means penyederhanaan. Accessed from KBBI online, 11 October 2020 at 21.40.

[11] Regulations of Dutch colonial legacy remain applicable under the provisions of Article I Transitional Provisions of the 1945 Constitution of the Republic of Indonesia, which state that: All existing laws and regulations shall remain valid until new ones under this Constitution come into effect.

[12] Analisa dan Evaluasi Peraturan Perundangundangan Peninggalan Kolonial Belanda [Analysis and Evaluation of Laws and Regulations of Dutch Colonial Legacy], National Law Supervisory Body Team, Ministry of Law and Human Rights under leadership of Prof. Dr. C.F.G. Sunaryati Hartono, 2015, p. 18.

[13] Bryan A. Garner, Black Law Dictionary, Ninth Edition, omnibus means relating to or dealing with numerous object or item at once; including many things or having various purposes.

[14] BUSROH, Firman Freaddy. KONSEPTUALISASI OMNIBUS LAW DALAM MENYELESAIKAN PERMASALAHAN REGULASI PERTANAHAN [CONCEPTUALIZATION OF OMNIBUS LAW TO SETTLE LAND AFFAIRS REGULATION ISSUE]. Arena Hukum, [S.1.], v. 10, n. 2, p. 227-250, Aug. 2017. ISSN 2527-4406. Available at: <https://arenahukum.ub.ac.id/index.php/aren a/article/view/327/269>. Date accessed: 14 Apr. 2019. doi:http://dx.doi.org/10.21776/ub.arenahuku m.2017.01002.4.

[15] Ibid. 
[16] SETIADI, Wicipto. SIMPLIFIKASI

REGULASI DENGAN MENGGUNAKAN METODE PENDEKATAN OMNIBUS LAW [REGULATORY SIMPLIFICATION USING OMNIBUS LAW APPROACH METHOD]. Rechts Vinding Journal: National Law Supervisory Media, [S.1.], v. 9, n. 1, p. 39, Apr. 2020. ISSN 2580-2364. Available at: <https://rechtsvinding.bphn.go.id/ejournal/in dex.php/jrv/article/view/408>. Date accessed: 10 Oct. 2020.

doi:http://dx.doi.org/10.33331/rechtsvinding .v9i1.408.

[17] Ibid.

[18] Ibid.

[19] Ibid.

[20] Ibid.

[21] Laica Marzuki, "Membangun UndangUndang Yang Ideal" ["To Build Ideal Laws"], Indonesia Legalization Journal Volume 4 No. 2, June 2007.

[22] HAS Natabaya, "Peningkatan Kualitas Peraturan Perundang-undangan (Suatu Pendekatan Input dan Output)" ["Improved Quality of Laws and Regulations (An Input and Output Approach)"], Indonesia Legalization Journal(Volume 4 No. 2, June 2007) p. 9.

[23] Moh. Mahfud M.D, Politik Hukum Indonesia [Indonesian Legal Politics], PT Raja Grafindo Persada, $7^{\text {th }}$ Print, Jakarta, 2017. pp. 4-6 .

[24] Accessed from http://www.moleg.go.kr/english/history on 11 October 2020 at 16.10.

[25] Ministry of Legislation of the Republic of Korea, Overview of Legislation System of the Republic of Korea,

http://unpan1.un.org/intradoc/groups/public/ documents/APCITY/UNPAN011552.pdf, accessed on 11 October 2020 at 16.15.

[26] The Office of Information and Regulatory Affairs, https://www.whitehouse.gov/omb/informati on-regulatory-affairs/, accessed on 11 October 2020 at 16.30 .

[27] Cabinet Legislation Bureau, https://www. Clb.go.jp/english.about.html, accessed on 11 October 2020 at 16.40.

[28] Department of the Prime Minister and Cabinet, https://www.pmc.gov.au/ accessed on 10 October 2020 at 16.45.

[29] Jimly Asshiddiqie, MK Siap Ambil Alih Wewenang MA Uji Aturan di Bawah UU [The Constitution Court is Ready to Take Over the Supreme court's Authority for
Review of Rules Below the Law], http://www.antaranews.com/print, accessed on 1 May 2019.

[30] Setiadi, W. (2019). "Institution Restructuring to Sustain Regulatory Reform in Indonesia", Hasanuddin Law Review, 5(1): 120-131.

[31] Sholahuddin Al-Fatih, Model Pengujian Peraturan Perundang-Undangan Satu Atap melalui Mahkamah Konstitusi [One-Stop Legislation Review Model through the Constitution Court], Legality, ISSN: 25494600, Vol.25, No.2, September 2017February 2018, pp. 247-260 